\title{
The survey of hydraulic facilities of the cascade of ponds of "Exhibition of Achievements of National Economy" landscape park
}

\author{
Lyudmila Frishter ${ }^{1, *}$ \\ ${ }^{1}$ Moscow State University of Civil Engineering, Yaroslavskoe shosse, 26, Moscow, 129337, Russia
}

\begin{abstract}
The artificial urban landscape of the exhibition complex type is being created on the territory of the modern complex of Exhibition of Achievements of National Economy "VDNKh" of the city of Moscow. It includes the hydraulic system based on the ponds of the Kamenka river with fountains and decorative pools. The purpose of the survey (inspection) is the assessment of the technical conditions of the hydraulic facilities of the cascade of ponds to determine the possibility of their further operation or the need of their rebuilding or fortifying of the constructions. There is also given a brief historical summary of the park complex formation and the operation of the ponds, the analysis of archival projects during 75 years of operation activity of the cascade of ponds and hydraulic structures. The article includes the conclusion formed on the results of the inspection of hydraulic structures of the cascade of ponds of the object of cultural heritage and tourist attraction of "VSKhV-VDNKhVVTs" - "The VDNKh landscape park" zone.
\end{abstract}

\section{Introduction}

The notion of "Smart City" means a well-organized and comfortable for living town. The plans of the urban improvement of the city of Moscow provide the establishment of the urban landscape of an exhibition complex type on the territory of the modern complex known as VDNKh exhibition complex or VDNKh [1,2]. The cascade of five ponds on the Kamenka river previously known as the Ponds of Main Botanical Garden of the Russian Academy of Sciences and VDNKh after the formation of the natural-historical park of "Ostankino" is named as the cascade ponds on the Kamenka river. The landscape park is being created on the basis of the ponds of the Kamenka river with fountains, decorative pools and the working system of hydraulic facilities [3, 4]. The ponds and the elements of hydraulic facilities are the part of the landscape park and are considered to be the subject of preservation.

The designing of the landscape park, including the hydraulic structures of the cascade of ponds [1] requires a detailed inspection (survey) of technical conditions of the dams and spillways $[5,6]$, which was the subject of the accomplished research works.

* Corresponding author: 1 frishter@mail.ru 
The purpose of the survey is getting the assessment of the technical conditions of the hydraulic facilities of the cascade of ponds to determine the possibility of their further operation or the need of their rebuilding or fortifying of the constructions.

\section{Brief historical information}

\subsection{Formation of the park complex}

The territory of VDNKh is a part of a pre-existing in the XVIII century vast forest of Ostankino estate owned by the Count N.P. Sheremetev. In the late 1780s N.P. Sheremetev was busy in the estate with the construction of a new palace, redevelopment and expansion of the old park. At the same time there were arranged six large and small ponds on the Kamenka river. This part of the park in the English landscape style with the alleys leading to the groves and hunting grounds was designed by the serf architect P.I. Argunov [7, 8]. The park has been planted with the decorative trees and bushes.

In the 30s of XIX century the "golden" era of landed estates was over and the territory of the park began to come to desolation so the park was just used for country house construction and as a place for citizens walks. By 1917 the most part of the estate had retained a substantial territory of partly depleted forest. In XX century the land of the park was no longer a distant suburb of Moscow but a museum complex included in the urban development.

Taking to the account the immense value of the natural array $[9,10]$, the architects fixed its main territory in the master plan of Moscow as the object of park type. Currently there was launched a setup of the landscape park, which includes a cascade of ponds with hydraulic facilities.

\subsection{Brief history of exploitation of ponds}

The spillways for the dams on the Kamenka river were built in 1939. Initially they were made of wood with wooden decking placed on the wooden piles. The survey made in 1948, revealed a low operation of the rotten wooden piles, so there were offered the options of the concrete spillways. The reconstruction of the ponds was carried out in 1950-1954. The wooden spillways were dismantled up to the wooden piles to build the reinforced concrete spillways on the preserved basis.

The regular reconstruction, rehabilitation and modernization work at the ponds was carried out from 1979 to 1982. In 1981-1982 there were developed executive drawings for the rebuilding of dams, spillway elements, bank reinforcement as well as the construction of the quay at the pond \#2 and restoration work for the refunctioning of ponds and dams.

Because of poor technical conditions the spillway in the dam between the ponds \#1 and \#2 was replaced in 2014, also there was provided the fragmented bank reinforcement.

\section{Survey of technical conditions of hydraulic structures of the cascade of ponds}

The cascade of ponds \#1 - \#5 includes four dams between the ponds to support the water pressure between the upstream and the downstream reach (canal pound), five spillways of the different types to discharge water into the low reach.

The objectives of the survey of the dams and the water throughput constructions are the of the structure description $[11,12]$, including photographic images of defects, damage and destruction of the structures [13-15], analysis of construction projects created within the 
period of more than 75 years of operation activity, including projects of reconstruction and modernization of the structures and ponds.

In accordance with the tasks of the research the following work have been performed: collection, processing, analysis of archives and operational documentation of "VSKhVVDNKh-VVTs", the necessary measuring work including the unsealed elements of constructions to compare with the project structures; flaw detection of the surface and underwater parts of the building constructions.

The technical condition of the inspected hydraulic structures is rated [13-15] as normal, satisfactory, unsatisfactory and unacceptable [6,7]. The safety integrity level of the structures according to the terminology of the Russian register of hydraulic structures is assessed as normal, low, unsatisfactory and dangerous. The class of surveyed hydraulic facilities is graded as IV, the level of structure responsibility is normal.

\subsection{Dams of ponds}

The cascade of ponds is formed with four dams: \#1 between the $1^{\text {st }}$ and $2^{\text {nd }}$ pond, \#2 between the $2^{\text {nd }}$ and $3^{\text {rd }}$ pond, $\# 3$ between the $3^{\text {rd }}$ and $4^{\text {nd }}$ pond, $\# 4$ between the $4^{\text {th }}$ and $5^{\text {th }}$ ponds. The dams are earth-made, homogeneous, low-pressure. The geometric characteristics of dams are shown in Table 1.

Table 1. The geometrical parameters of dams

\begin{tabular}{|c|c|c|c|c|}
\hline Geometrical parameters & Dam \#1 & Dam \#2 & Dam \#3 & Dam \#4 \\
\hline Pressure H at flood-control storage level, $\mathrm{m}$ & 2.3 & 6 & 3.9 & 3.2 \\
\hline Maximum height, m & 5.2 & 9 & 8 & 6.6 \\
\hline The width along the ridge, $\mathrm{m}$ & 7.5 & 11 & 7 & 10.6 \\
\hline The length of the ridge, $\mathrm{m}$ & 70 & 90 & 115.5 & 126.6 \\
\hline $\begin{array}{c}\text { The width of the road along the ridge } \\
\text { The minimum stock of the ridge concerning } \\
\text { to flood-control storage level }\end{array}$ & 7.5 & 1.95 & 2.45 & 2.4 \\
\hline \begin{tabular}{c} 
Laying the side slope upstream/downstream \\
\hline
\end{tabular} & $4.8 / 9.3$ & $7.4 / 20$ & $6.1 / 12$ & $7.4 / 20$ \\
\hline
\end{tabular}

The reserve of ridge for all the dams over the flood-control storage level is sufficient. The dam ridge is used for pedestrian walking and official transport movement. The width of the road along the ridge is shown in the Table 1.

The fixing of the upstream and downstream slopes of the dam is of grassing-type. There is no processing of the upstream slope of dams and the ground cover of the overwater upstream slope is of satisfactory quality. The signs of running drainage devices were not detected.

In the area of the downstream canal pound of dams was detected the silting area (of reeds and grass). Both the scheme of pond silting and the project of the cleaning of pond 
beds are available in the archival materials of 1979. At the same time the present state of silting areas coincides with those shown on the scheme of the siltation of ponds from 1979 that characterizes the temporal operating stability of the ponds ecosystem.

The downstream slope of dams \#2 and \#3 shows the vegetation overgrowth. The grass cover of the downstream slope has bald spots and gullies, starting from the ridge of the dam. The drainage systems along the downstream slope of dams is missing.

\subsection{Spillways of ponds.}

\subsubsection{The first stage of the cascade}

The first stage of the cascade between the ponds \#1 and \#2 includes earthen-made dam and the low pressure surface spillway $[4,11]$. The spillway $1-2$ between the $1^{\text {st }}$ and $2^{\text {nd }}$ pond is located in the body of the dam and is adjacent to the high right bank. The axis of the spillway and the axis of the dam intersect each other at right angles. The spillway is made of reinforced concrete.

The analysis of archival materials detected the documents on previously made projects of spillway: of wood and reinforced concrete; the materials about the modern spillway 1-2 were not detected.

From the side of pond \#1 the supply channel is small. The input head spillway (transit area) in the form of a horizontal concrete slab has one span of $4.3 \mathrm{~m}$ wide and about $4.5 \mathrm{~m}$ in length. The span of the input head spillway is blocked with flat wooden sluice boards. The space over the two last opposite spans of sluice boards has a waste detaining grids with dimensions - 1000x500 mm. The grids are regularly serviced.

The bridge over the spillway along the ridge of the dam is based on the longitudinal walls of the spillway and two ducts (channels) with dimensions - 300x100 mm. The race (chute) is straight on the plane and has a rectangular cross-section and the concrete retaining walls of constant width along the sides. The angle of the race is $19^{\circ}$. The end section of the race is made as a hydraulic-jump stilling basin with a jet knocking springboard at the end. The bank abutments are made by the type of splayed wall. Along the race there is an installation of filtration flow under the structure and the side walls of race (chute). The reduction of the filtration pressure is attained with a decrease in depression curve of drainage behind the chute walls and under the structure. There is a rock blanket working as a drainage near the abutment adjacent to the dam.

\subsubsection{The second stage of the cascade}

The second stage of the cascade between the pond \#2 and \#3 includes the earthen-made dam and the shaft spillway with the bottom water outlet. The archival material has the master plan of structures of 1950 and the technical project of restoration of the pond $\# 2$, showing the shaft spillway and the bottom water outlet, the dam $\# 2$ between the $2^{\text {nd }}$ and $3^{\text {rd }}$ pond, a floodway, which has not remained to the present time. The documentation on the spillway 2-3 in a modern condition could not be found. The main part of the shaft reinforced concrete spillway is a vertical shaft. A free-falling stream of water flows into the shaft through the superficial square head of the spillway. The head of the spillway is made of reinforced concrete. The flat ridge of the spillway has dimensions $2.4 \times 2.45 \mathrm{~m}$. The sluice boards are installed on the spillway to drain water. The protection grid is set in front of the spillway. The concrete preparation is made at the bottom of the shaft.

The bridge leads to the head wall of the spillway. The drainage channel is made of precast reinforced concrete chutes of L-4 brand with the grouting of joints; the channel is 
made on the sand-gravel preparation of $\mathrm{t}=200 \mathrm{~mm}$. Before the spillway tower there are bottom silt deposits. The measured thickness of the layer of deposits is equal to $1.6 \mathrm{~m}$. In the overflow in the downstream canal pound were also noted silting and bogging processes. The survey has revealed the following major defects and damage:

- surface corrosion of metal structures with the peeling paint layer;

- corrosion of the working reinforcement of the head wall plate;

- local destruction of the concrete tower of the spillway;

- vegetation exists in the gaps between the elements of the structure of the spillway;

- moistening of the surface and efflorescence on the overflow's wall due to of the flow filtration outlet;

- plate corrosion of metallic spacers of the overflow with corruption up to $80 \%$ of section.

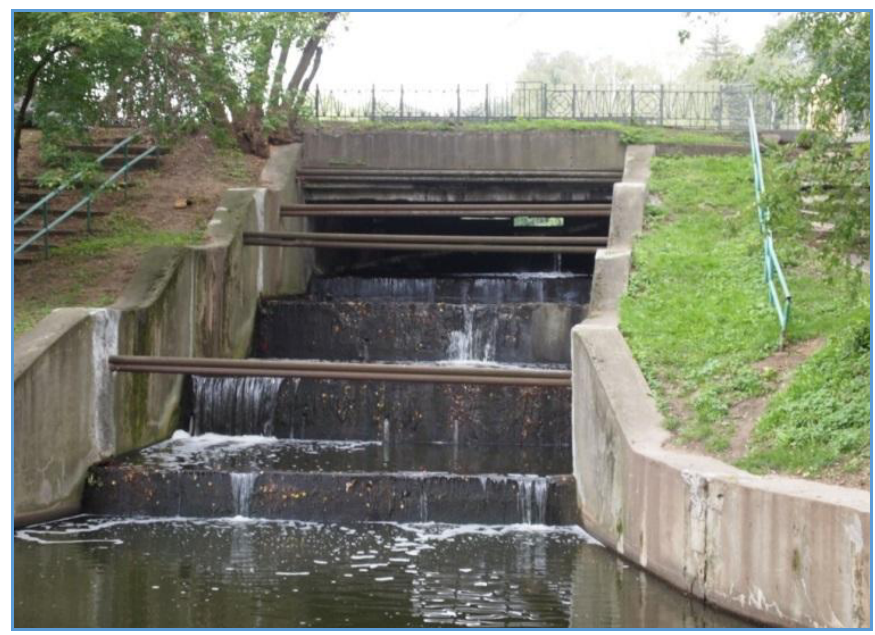

Fig. 1. The stepped drop of the spillway dam\#3 from the downstream reach

\subsubsection{The third stage of the cascade.}

The third stage of the cascade between the $3^{\text {rd }}$ and $4^{\text {nd }}$ pond includes an earthen-made dam, open adjustable surface spillway in the dam body with a stepped water drop (Fig 1) and the broken shaft spillway with a bottom water outlet (flow).

The measured geometric parameters for an open stepped spillway 3-4 (Fig. 1) correspond to the project. The axis of the spillway and the dam axis intersect each other at a right angle in $40 \mathrm{~m}$ from its left bank abutment. All the structural elements of the spillway are made of reinforced concrete.

The structure of the spillway 3-4 includes: a) the head part - water receiver in the form of the surface hole, the transitional part of the head wall, b) the water outfall part in the form of a stepped overflow spillway c) the end part of the spillway that provides pairing of the discharged flow with the downstream reach.

Transitional part of the spillway water receiver is a horizontal slab with a size of $6.2 \times 7.6$ $\mathrm{m}$. The opposite spans of the sluice shutter (gate) are currently covered with metal sheets $t$ $=5 \mathrm{~mm}$, welded to the uprights of the shutter.

The pairing with an earthen-made dam at the stepped drop is made in the form of diving concrete abutments, expanding at the bottom. The end part of the overflow of the spillway is made as stilling basin with a bell in order to reduce the unit water quantity.

The spacers along the step width of the pipe are $\varnothing 100 \mathrm{~mm}$ were installed later and are embedded in the concrete walls using crushed bricks with a cement-sand mortar. 
The step drop has 3 steps of a width about $6.0 \mathrm{~m}$ and lengths (between the expansion joints): 1st stage - about $4.4 \mathrm{~m}$, 2nd stage - about $4.9 \mathrm{~m}$, 3rd stage - about $4.8 \mathrm{~m}$.

The slab of bottom water well has a length of about $5.2 \mathrm{~m}$ and is expanding in the plan.

To enhance the effect of energy dissipation the steps are made as a stilling basin. The steps are separated from each other by vertical seams for the thermal stress relief and for the independent settlement of the steps. At the end of each step are water-jet tooth and drainage of two pipes of $\varnothing 75 \mathrm{~mm}$.

The filtration flow runs behind the side walls and under the base along the stepped overflow spillway. The drainage along the line of the underground contour of the spillway was not detected, so the depression curve established behind the walls, determines the pressure of the filtration behind the walls of the spillway.

The action of seasonal temperatures: freezing the abutments of the side walls of the spillway and the adjacent ground and their thawing in the warm season provides the disclosure of water saturated functional joints in the walls of the spillway overflow. The space of joints is filled with sand, small staff entered because of filtration.

Inspection of spillway [13-15] shows the following main damage:

- disclosure of functional joints due to filtration, temperature effects and the settlements, poor maintenance of the spillway of the dam \#3. A joint opening throughout the of the wall thickness;

- concrete damage on the surface of the walls of the spillway;

- horizontal $40 \mathrm{~mm}$ shift along the strain seam of the lower portion of the left wall;

- significant corrosion of the reinforcement structure in the areas of opening functional joints;

- the absence of metal pipes-spacers; corrosion of the metal profiles in the slab overlapping the hole of the water receiver, surface corrosion of metal sheets on the sluice gate and the metal pipes-spacers;

- drainage clogging of the overflow spillway steps; siltation located near the walls of the water wells.

The inactive shaft spillway 3-4, was designed to discharge water from the pond\#3 to the pond\#4. It was made of reinforced concrete and has a vertical shaft about $4.4 \mathrm{~m}$ in height. The head wall of the spillway has a size of $2.8 \times 2.8 \mathrm{~m} 2$. The piles of the shaft basement and the dowels along the perimeter of the foundation are wooden (come up to the project).

The survey of the spillway shows the following main defects and damage:

- the collapse of the protective layer of concrete with the exposure and substantial corrosion of the reinforcement structures of the spillway;

- a large crack in the pairing area of the bridge and the slab of the head wall;

- the cracks in the connection area of the bridge and the head wall;

- the erosion of the slope above the retaining wall at the exit site of the pipe of the bottom spillway.

\subsubsection{The fourth stage of the cascade}

The fourth stage of the cascade between the pond \#4 and \#5 includes an earthen-made dam and a shaft spillway with a bottom water outlet (flow).

The shaft spillway was originally built of wood in 1939. In 1948. a project to restore the destroyed spillway was made in three versions: wooden, concrete, reinforced concrete $[4,8]$. In 1950 a note about the implementation of repair works was left. The adopted version of the reinforced concrete spillway was built in 1950 and is currently working. The original design of the spillway including lattice bridge fences and lifting mechanisms of sluice boards have still remained. During the survey the measured geometric parameters of the 
working spillway have shown the correspondence to the project. The shaft spillway made of reinforced concrete has a vertical shaft about $3.6 \mathrm{~m}$ in height. The head of the spillway has a size $4.2 \times 5 \mathrm{~m}$. The slab of the spillway head includes two inspection hatches with dimension size of $1.25 \times 1 \mathrm{~m} 2$.

There are two rows of stop-planks installed in the spillway to drain water. The protection grid is set on the bottom of the spillway.

The base of the shaft of the waters receiver is concrete rested on the hard-packed gravel with the cement mortar. The thickness of the foundation slab (according to the project) is $1.25 \mathrm{~m}$. The metal pipes of the deep sluice with diameter of $1.2 \mathrm{~m}$ are located in the trench made of sand-gravel-clay building mixture.

The bridge with length of $13.6 \mathrm{~m}$ leads to the spillway. The construction of the bridge is monolithic reinforced concrete ribbed slab $(\mathrm{t}=270 \mathrm{~mm})$. The rails, installed on the bridge, correspond to the project of the spillway rebuilding of 1950 .

The survey of the spillway 4-5 shows the following damage (Fig. 2):

- unacceptable damage of reinforced concrete structures of the head wall: the protective layer of concrete is destroyed; the corrosion damage of reinforcement is up to $20 \%$;

- significant damage to concrete in the top of the shaft walls with exposed concrete reinforcement in the certain areas of the variable level area;

- unacceptable damage of the ribs of the bridge slab: the collapse of the protective layer of concrete, substantial corrosion of the slab reinforcement;

- corrosion of the lifting mechanisms of the sluice boards; the thickness of silt bottom deposits in front of the spillway tower is $0.5 \mathrm{~m}$.

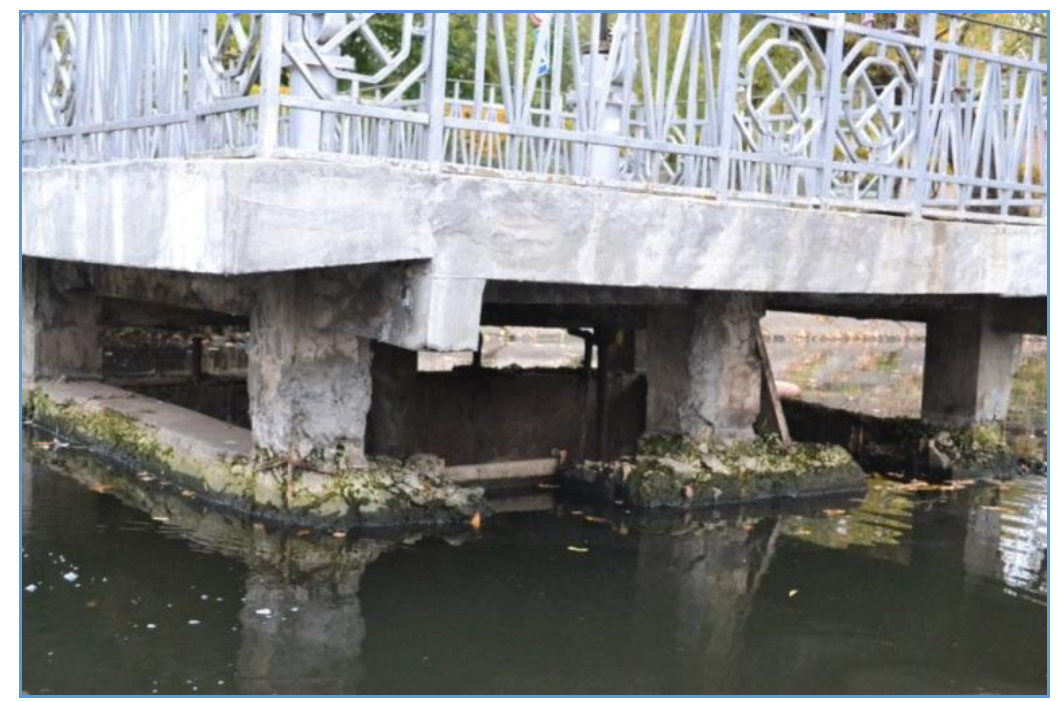

Fig.2. Shaft spillway of the dam \#5. Two water inlet holes. Ruined concrete of the head wall of the water receiver and the bridge abutments. Lattice fences are original, designed in 1950

\section{Conclusions}

The results of technical survey of the hydraulic structures of the cascade of ponds: dams, spillways, determine the technical condition of hydraulic structures and the level of safety of their work according to the terminology of the Russian Federation register of hydraulic structures. The data of survey and recommendations for rehabilitation, reconstruction of the structures are given in table 2 . 
Table 2. Evaluation of the technical condition and the safety level of structures

\begin{tabular}{|c|c|c|}
\hline Structures & $\begin{array}{l}\text { Technical } \\
\text { condition; } \\
\text { safety level }\end{array}$ & Recommendations \\
\hline \multicolumn{3}{|c|}{ The $1^{\text {st }}$ stage of cascade: pond \#1-pond \#2. Inspection of dam \#1 } \\
\hline Dam \#1 & $\begin{array}{l}\text { normal; } \\
\text { normal }\end{array}$ & Repair of damaged grassing in certain areas \\
\hline $\begin{array}{l}\text { Overflow } \\
\text { spillway } 1-2\end{array}$ & $\begin{array}{c}\text { normal; } \\
\text { normal }\end{array}$ & $\begin{array}{l}\text { 1. Repair of the column shears of the sluice boards } \\
\text { 2. Reset of water from the roadway beyond the bridge, removal } \\
\text { of rain and melt water on the lower slope of the construction } \\
\text { 3. Current repair of the lower surface of the bridge slab (at the } \\
\text { humidification section) }\end{array}$ \\
\hline \multicolumn{3}{|c|}{ The $2^{\text {nd }}$ stage of cascade: pond \#2-pond \#3. Inspection of dam \#2 } \\
\hline Dam \#2 & $\begin{array}{l}\text { satisfactory; } \\
\text { unsatisfactory }\end{array}$ & $\begin{array}{l}\text { 1. Repair of the road surface along the ridge of the dam } \\
\text { 2. Repair of scours and grassing on the lower slope of the dam }\end{array}$ \\
\hline $\begin{array}{c}\text { Shaft } \\
\text { spillway 2-3 }\end{array}$ & $\begin{array}{l}\text { unsatisfactory; } \\
\text { low }\end{array}$ & Overhaul of spillway with the replacement of the head wall \\
\hline \multicolumn{3}{|c|}{ The $3^{\text {rd }}$ stage of cascade: pond \#3-pond \#4. Inspection of dam \#3 } \\
\hline Dam \#3 & $\begin{array}{l}\text { unsatisfactory; } \\
\text { low, near to } \\
\text { unsatisfactory }\end{array}$ & $\begin{array}{l}\text { 1. Repair of the road surface along the ridge of the dam } \\
\text { 2. Repair of scours and grassing on the lower slope of the dam }\end{array}$ \\
\hline $\begin{array}{l}\text { Overflow } \\
\text { spillway 3-4 }\end{array}$ & $\begin{array}{l}\text { satisfactory; } \\
\quad \text { low }\end{array}$ & $\begin{array}{l}\text { Repair of damaged structures in the areas with a robust design } \\
\text { of the expansion joints in the walls of the stepped drop }\end{array}$ \\
\hline $\begin{array}{l}\text { Spillway } 3-4 \\
\text { (inactive) }\end{array}$ & $\begin{array}{l}\text { unsatisfactory; } \\
\text { unsatisfactory }\end{array}$ & Overhaul of the spillway \\
\hline \multicolumn{3}{|c|}{ The $4^{\text {th }}$ stage of cascade: pond \#4-pond \#5. Inspection of dam \#4 } \\
\hline Spillway 4-5 & $\begin{array}{l}\text { unacceptable; } \\
\text { dangerous }\end{array}$ & $\begin{array}{l}\text { Overhaul with the replacement of construction of the head wall } \\
\text { and the bridge }\end{array}$ \\
\hline
\end{tabular}

The results of the technical survey of the hydraulic structures of the cascade of ponds were transferred for the development of the project to adapt to the modern use of the territory as a part of cultural heritage and tourist attraction of "VSKhV-VDNKh-VVTs" - "The VDNKh landscape park" zone at the address: Moscow, Mira Prospect, ow. 119.

\section{References}

1. Landscape Architecture and Environmental Engineering from the project to the economy - 2016: Proceedings of the V Int. Sc. Conf. (Saratov LLC «TseSAin», 2016)

2. O.B. Sokolskaya, V.S. Teodoronsky, Specialized facilities of landscape architecture: design, construction, maintenance (Lan, 2015)

3. E.D. Sabo, V.S. Teodoronsky, A.A. Zolotarevskii, Hydraulic reclamation of the landscape construction objects (Academia, 2008) 
4. M.V. Nesterov, Hydraulic facilities (Novoe znanie, 2006)

5. O.M. Schursky, Hydraulic engineering, 1, 8 (2014)

6. V.A. Volosuhina, The collection of normative-methodical documents used in the declaration of safety of hydraulic structures (Academy of Security GTS, 2014)

7. S.S. Ozhegov, The history of landscape architecture (Architecture, 2004)

8. V.S. Teodoronsky, I.O. Bogovaya, The objects of landscape architecture (MFSU, 2003)

9. M.M. Vasiukov, To the question of the formation of green space along the nature trails in protected areas of Moscow (2011)

10. V.L. Mashinskii, Green resources fund - the part of nature. Urban design of terrains of green resources fund of the urban settlements (Sputnik, 2006)

11. A.G. Bespalov, A.L. Salnikov, O.N. Bespalov, S.A. Davydov, Hydraulic facilities (KNORUS, 2016)

12. L. Frishter, P. Ivanov, Procedia Engineering, 165, 1035 (2016)

13. SP 58.13330-2012 Standard of the Russian Federation

14. GOST 31937-2011 Standard of the Russian Federation

15. GOST R 53778-2010 Standard of the Russian Federation 